\title{
Jak sledovat aortální stenózu?
}

\author{
Petr Niederle \\ Kardiologické oddělení, Nemocnice Na Homolce, Praha, Česká republika
}

Se zájmem a se zaujetím jsem si přečetl v 11 . čísle Cor et Vasa (2005) úvodník profesora Romana Čerbá$\mathrm{ka}$, jenž je vlastně komentářem $\mathrm{k}$ přehlednému člán$\mathrm{ku}$ Michala Padoura a spol. $\mathrm{Z}$ našeho oddělení. ${ }^{(2)}$ Nejsou žádné pochyby, že R. Čerbák představuje generaci katetrizátorů (invazivních kardiologů) $z$ období získaných srdečních vad. Bylo to krásné období invazivní diagnostiky, zhodnocení stupně a významnosti mitrálních a aortálních stenóz, které poučilo mnohé mladší kolegy o hemodynamice vad a významu srdeční katetrizace vůbec. Bylo to také období mnoha mých učitelů, na které nemohu nevzpomenout - Ressla (IKEM), Ježka (Ústav fyziologických regulací, Bulovka), Endryse a Kvasničky (Hradec Králové), Čerbáka (Brno), Šerfa a Kučery (VFN Praha). Z nich v současné době aktivně působí pouze čtyři osobnosti, které jsou dosud činné v české kardiologii - Roman Čerbák, Jiří Kvasnička, Pavel Jebavý a snad i Jiří Endrys.

Ale dosti sentimentu a pojd'me k tématu. Význam chlopennich vad klesá s jejich výskytem. Je pravdou, že porevmatické aortální či mitrální vady vidíme v klinické kardiologii zcela výjimečně. Je to díky obrovské preventivně-léčebné péči v uplynulých letech, zkvalitněné a rychlé diagnostice i ústupu revmatické horečky z evropských zemí a přesunu jejího výskytu do zemí Dálného východu. Z empirické zkušenosti si dovoluji tvrdit, že porevmatické vady $\mathrm{v}$ současnosti tvoři méně než $5 \%$ našich katetrizovaných nemocných. Když jsem byl poprvé v roce 1986 v USA na studijním pobytu ve Washingtonské univerzitní nemocnici v Seattlu, byl jsem překvapen vysokou frekvencî degenerativních aortálních vad, především stenóz. Protože však primárně neodmítám hypotézy, řekl jsem si, že do 10 let to bude u nás asi podobné. Mýlil jsem se o dalších 10 let. V nynější době činí degenerativní aortální stenózy převážnou část našich diagnostikovaných vad, ač jejich významné množství zůstává pod hranicí hemodynamické významnosti. Dá se říci, že devět $z$ deseti aortálních stenóz je degenerativního původu. Otázkou zůstává, proč se tak často vyskytujî? Já jsem osobně přesvědčen, že ate-

Adresa: prof. MUDr. Petr Niederle, DrSc.,

F.A.B.I., Kardiologické oddělení, Nemocnice Na Homolce, Roentgenova 2, 15030 Praha 5, Česká republika,

e-mail: petr.niederle@homolka.cz roskleróza a pokročilý věk (možná i infekční etiologie - Chlamydie? Helicobacter?) ${ }^{(3)}$ jsou hlavními přičinami této skutečnosti. Naše populace ve srovnání s lety totality přeživá zhruba o deset let déle a právě toto „stárnutí“ v dobrém slova smyslu způsobuje vyšší výskyt všech degenerativních onemocnění, jež jsme dřive nebyli zvyklí vídat. Aortální stenóza je $z$ nich nejčastější srdeční vadou. Její prevalence udávaná různými autory kolísá mezi 4-31\%.(3,4) V selektované populaci kardiologických nemocných jsme pred lety odhalili výskyt degenerativní aortální stenózy různého stupně prribližně ve $30 \%$, ale alarmující skutečností z oné doby bylo, že terénní/praktický lékař o ní uvažoval jen asi u jedné čtvrtiny nemocných. ${ }^{(5)}$ Já, ač speciálním zaměřením především echokardiolog, jsem se musel naučit diagnostikovat i velmi diskrétní morfologické změny na aortální chlopni, které však často progredují do její stenózy. Jelikož nejsem v oboru začátečník, řekne mi i způsob pohybu chlopně při jejím otvírání náznak jejî rigidity, způsobené degenerativním postižením. Správná diagnóza je počátkem procesu, jenž dostatečně popsal Michal Pad’our v přehledném článku.

Zůstává tedy otázkou, co s aortální degenerativnî stenózou jak před úspěšnou operací, tak i po ní. Jsem zastáncem myšlenky, že rozpoznanou degenerativní stenózu je nutné dispenzarizovat a podle její hemodynamické významnosti/nebo přidruženého koronárního postižení sledovat $\mathrm{v}$ jistých časových intervalech. Lékař nebo pracoviště, jež stanoví danou diagnózu, by mělo předat pacienta do kardiologického sledování tehdy, jde-li o symptomatologii (klasifikace NYHA, únavnost, námahová angina pectoris či synkopa - zvláště při práci s rukama nahoře!) a tento kardiolog by zároveñ měl provádět nebo požadovat cílené echokardiografické kontroly a ve vhodné době indikovat kardiochirurgický výkon. Zde je, Romane Čerbáku (ale on to ví), v průběhu let vzniklé přehodnocení významu katetrizace a neinvazivního ultrazvuku u některých chlopenních vad. Čistá aortální, ale i mitrální stenóza nepotřebuje katetrizaci, pouze doplnění koronarografie. Nevzpomenu si přesně kdy, ale přibližně $\mathrm{v}$ polovině devadesátých let (Invazivnî kardiologie ve Strážnici) jsem tento názor jasně deklaroval a i tehdejší předseda této společnosti (J. Fabián) mi dal za pravdu. Moderní echokardiografie v rukou zkušeného a věci znalého odborníka totiž 
dokáže s minimální nepřesností vůči přimo naměřeným hemodynamickým hodnotám určit závažnost aortální vady, v tomto případě stenózy. Zůstává otázkou, která měření jsou objektivnější. Zda je to katetrizace, měřená $\mathrm{v}$ podmínkách pro pacienta stresových, nebo echokardiografie, při níž si nemocný pohodlně leží (někdy i usíná) a ví, že se mu nic invazivního nebude činit. Kromě určení diagnózy a stupně významnosti vady je předností echokardiografie možnost popisu morfologie a pohybu cípů chlopně (počet cípů, jejich individuální postižení - diskrétně či hrubě fibrózní, lokalizace a rozsah kalcifikací, parciálně zachované nebo téměř zaniklé systolické otvírání, rozměr aortálního kořene), což představuje velmi cennou informaci pro kardiochirurga. Většina z těchto údajů se dá katetrizačně určit jen s mnohem menši přesností, pokud vůbec. (Hodnocení morfologie a funkce levé komory přesahuje rámec tématu.) I přes všechno výše uvedené, existují (i když dnes jen výjimečně) invazivní kardiologové, kteři si indikaci aortální stenózy bez katetrizačního vyšetření nedovedou představit. Mým názorem je, že mají pravdu jen $\mathrm{v}$ případě velmi nekvalitního echokardiografického zobrazení způsobeného nevyšetřitelností pacienta.

Další závažnou otázkou zůstává osud nemocného po provedené operaci (náhrada aortální chlopně mechanickou chlopní či bioprotézou). Dobrým zvykem zodpovědného kardiocentra bývá nejméně jednou po propuštění do domácího ošetření zkontrolovat pacienta ambulantně, jak chirurgicky, tak i kardiologicky a to obvykle v rozmezi jednoho až dvou měsíců po výkonu. Nedílnou součástí ambulantního vyšetření musí být adekvátní antikoagulační kontrola, resp. antiagregační terapie. V připadě jakýchkoliv pooperačních komplikací je vhodné takové sledování prodloužit až do jejich úplného zhojení. Jelikož počet operovaných aortálních stenóz narůstá, není možné aby všechny nemocné po operaci ambulantně dispenzarizovalo příslušné kardiologické oddělení dané nemocnice. Proto se nemocní, a to platí zejména pro osoby s trvalým bydlištěm mimo spádový region, většinou předávají do péče spádového kardiologa $\mathrm{k}$ další dispenzarizaci a ambulantním kontrolám. Tento typ sledování byl deklarován, bohužel jen velmi heslovitě, v Doporučených postupech ... z roku 2000. ${ }^{(6)}$ Domnivám se, že ambulantních i klinických kardiologů pracujících $\mathrm{v}$ regionálních interních ambulancích i nemocnicích by měl být dostatek. V době zveřejnění poslední verze Národního kardiovaskulárního programu se počítalo s nárůstem počtu specializovaných-atestovaných kardiologů $16-20$ ročně. ${ }^{(7)}$ Skutečností je, že specializační atestaci skládá ročně asi 30 i více lékařů. I když zajisté dochází $\mathrm{k}$ přirozenému úbytku danému penzijním věkem, věřím, že nemáme kardiologů nedostatek. Role územního specialisty by měla spočivat $\mathrm{v}$ klinických a laboratorních kontrolách (zejména antikoagulační léčby a jejího přiměřeného dávkování (s INR 2,0-3,9 - podle typu použité protézy; ${ }^{(8)}$ INR 2,0-3,0 pro aortální protézy $\left.{ }^{(9)}\right)$.

Frekvence kardiologických kontrol je určována individuálně (nejméně však dvakrát ročně, INR po 4-6 týdnech). Při kontrolách je nezbytné poslouchat srdce nemocného a hodnotit ostrost kliků protézy, nebot' změna $\mathrm{v}$ poslechovém nálezu může znamenat poruchu její funkce. Zásadním výstupem kontrolní- ho vyšetřování by mělo být konstatování správné funkce chlopenní náhrady a nehoršící se klinický profil nemocného. Samozřejmou součástí kontrolních vyšetření by měla být echokardiografická kontrola, potvrzující normální nález na protéze a prokazující regresi případné předoperační hypertrofie levé komory, resp. regresi její velikosti a zlepšení, nebo alespon̆ zachování její funkce.

U mechanických protéz sledujeme při kvalitním ultrazvukovém zobrazení jejich morfologii, amplitudu otvírání disku/listů a existující transvalvulární gradient, resp. jejich účinné průtokové ústí. Za důležité považujeme rozlišení trombu od narůstajícího pannu nebo bakteriální vegetace. Trombus i vegetace se jeví jako méně echogenní (,měkká“ echa) než přerůstající tkán̆, vegetace jsou často vlající. $V$ případech jejich nárůstu dochází $\mathrm{k}$ omezení pohybu disku/listů až $\mathrm{k}$ obstrukci protetického ústí. U většiny mechanických náhrad existuje stopová centrálně uložená regurgitace. V důsledku povolení jednoho nebo několika stehů upevñujících prstenec protézy $\mathrm{k}$ aortální stěně zjištujeme excentricky lokalizovanou paravalvulární regurgitaci. Rychlá a spolehlivá diagnóza těchto komplikací je doménou dopplerovského echokardiografického transthorakálního i jícnového vyšetření. Dojde-li k jakýmkoliv klinickým či echokardiografickým pochybnostem, měl by být nemocný doporučen $\mathrm{k}$ superkonsiliárnimu vyšetření na pracovišti, kde byl operován. Zvláště se to týká podezření na trombózu/pannus nebo uvolnění protézy s následky nárůstu transvalvulárního gradientu a paravalvulární regurgitace. Mechanické selhání funkce protézy z dưvodu poškození či primární vady materiálu je nesmírně vzácné; tato problematika není v současné době dostatečně popsána. „Mismatch pacient-protéza“ (aortální kořen vs. velikost protézy) se nachází u přiliš úzkého původního aortálního kořene/anulu, do něhož je implantována protéza s relativně malým ústím. U takových nemocných nacházime již při klidovém vyšetření zhruba středně významný transprotetický gradient, který při zátěžovém vyšetření mưže dosáhnout hemodynamické významnosti a tlakově zatěžovat levou komoru. Kardiochirurgická korekce bývá v těchto připadech nezbytná. V současné době se takovým pacientům obvykle implantuje náhrada ascendentní aorty včetně chopně. Bioprotézy podléhají degenerativnímu procesu podobně jako chlopně nativní. Proto je nezbytné sledovat pravidelnými echokardiografickými kontrolami změnu jejich kvality a nárůst gradientu.

Ambulantní kardiolog musí také sledovat přitomnost nebo prohlubující se anemii pacienta, která může být způsobená reologickou interakcí (shear stress) proudící krve s protézou. Její léčba doplněním krevního objemu transfuzemi, železem a folátem je plně indikována.

O jiná přidružená nebo souběžná onemocnění (napřiklad respirační infekce) by se měl starat praktický lékař, podle potřeby ve spolupráci s jiným specialistou.

Jelikož jsem výše předestřel svůj vlastní a subjektivní názor, považuji za vhodné, aby se k celé problematice vyjádřrili přednostové kardiochirurgických a kardiologických pracovišt' existujících Kardiocenter a abychom dospěli $\mathrm{k}$ jednotnému názoru. Končím tedy otázkou: „Neměla by být doplněná/inovovaná stávající Doporučení pro sledování a léčbu ne- 
mocných s chlopennimi náhradami?, nebo vytvořena zcela samostatná guidelines?"

\section{LITERATURA}

1. Čerbák R. Aortální vada - nejčastější chlopenní vada současnosti. Cor Vasa 2005;47:409-11.

2. Pad’our M, Kupec J, Mráz T, a spol. Diferencovaný přístup k léčbě aortální stenózy. Cor Vasa 2005;47:423-30.

3. Čerbák R. Aortální stenóza nemocných staršího věku. Cor Vasa 2000;42:210-3.

4. Vambera M, Šulda M, Šindelářová Š, a spol. Aortální stenóza - úskalí kvantifikace a zvláštnosti ve starším věku. Cor Vasa 2000;42:224-9.
5. Niederle P, Henyš P, Mandysová E, a spol. Výskyt a charakter degenerativního postižení aortální chlopně u starší generace. Prakt Lék 2002;82:78-80.

6. Frídl P, Marek T, Čerbák R, a spol. Doporučené postupy pro diagnostiku a léčbu nemocných s chlopenní vadou v dospělosti. Cor Vasa 2000;42:K82-K86.

7. Česká kardiologická společnost, Česká společnost kardiovaskulární chirurgie, Česká angiologická společnost ČLS JEP: Národní kardiovaskulární program.

8. Garcia MV. Proshetic valve diasease. In: Topol EJ. Textbook of cardiovascular medicine. Philadelphia, New York: Lippincott-Raven Publ., 1998:579-605.

9. Kaza AK, Kern JA. Surgical treatment of valvular heart disease. In: Crawford MH, DiMarco JP. Cardiology. London: Mosby, 2001:Chapter 6.16. 